\title{
Best Practice Berbasis Komunitas Dalam Mewujudkan Ketahanan Masyarakat Terhadap Bencana
}

\author{
Syahrizal Koem*1, Rakhmat Jaya Lahay², Salmun K. Nasib ${ }^{3}$, Mahrifat Ismail ${ }^{4}$ \\ 1,2,4Program Studi Pendidikan Geografi, Fakultas Matematika dan IPA, Universitas Negeri Gorontalo \\ 3Program Studi Statistika, Fakultas Matematika dan IPA, Universitas Negeri Gorontalo \\ *e-mail: s.koem@ung.ac.id ${ }^{1}$, rjlahay@ung.ac.id ${ }^{2}$, salmun@ung.ac.id ${ }^{3}$, mahrifatismail@gmail.com
}

\begin{abstract}
Community-based programs emphasize the community as the main actor. It started with recruitment and the establishment of community forums which became the benchmark for the success of the program. Furthermore, the community is equipped with knowledge about the identification and utilization of village potential so that the community can play practical roles in maintaining the balance of the ecosystem in the context of disaster control. The involvement of community forums in best practice is an efficient means because it provides space for forums to exchange knowledge and ideas in offering problem-solving solutions. The mining potential in Hulawa Village has a strategic role in improving the community's economy. However, it has an impact on river water resources in Hulawa Village. The direct impact observed in the field is the color change in river water due to mining activities. The potential of the village-owned by Hulawa Village can be maximized to become a village advantage. This needs to be done because it sees the opportunity for the high involvement of the Hulawa village community in village community empowerment programs.
\end{abstract}

Keywords: Disaster Resilience; Community Participation; Community Perspective

\begin{abstract}
Abstrak
Program berbasis komunitas menekankan pada masyarakat sebagai aktor utama. Diawali dengan rekrutmen dan pembentukan forum komunitas yang menjadi tolak ukur keberhasilan program. Selanjutnya komunitas tersebut dibekali dengan pengetahuan tentang identifikasi dan pemanfaatan potensi desa sehingga komunitas dapat melakukkan peran-peran praktis dalam menjanga keseimbangan ekosistem dalam konteks pengendalian bencana. Keterlibatan forum masyarakat dalam best practice merupakan sarana yang efisien karena memberikan ruang bagi forum untuk saling bertukar pengetahuan dan ide dalam menawarkan solusi pemecahan maslah. Potensi tambang yang terdapat di Desa Hulawa memiliki peran starategis dalam meningkatkan ekonomi masyarakat. Namun, memiliki dampak terhadap sumber daya air sungai di Desa Hulawa. Dampak langsung yang diamati dilapangan yaitu perubahan warna pada air sungai akibat aktivitas pertambangan. Potensi desa yang dimiliki oleh Desa Hulawa dapat dimaksimalkan menjadi keunggulan desa. Hal ini perlu dilakukan karena melihat peluang tingginya keterlibatan masyarakat desa Hulawa dalam program-program pemberdayaan masyarakat desa.
\end{abstract}

Kata kunci: Ketahanan Bencana; Partisipasi Komunitas; Perspektif Masyarakat

\section{PENDAHULUAN}

Pengendalian krisis yang disebabkan oleh bencana alam dan kesehatan, telah mendorong manusia meningkatkan kapasitas dalam skala individu dan organisasi. Proses ini tentunya membutuhkan strategi dalam mewujudkan tujuan yaitu tangguh dalam menghadapi kondisi yang tidak normal. Krisis yang belakangan ini terjadi menuntut perubuhan yang signifikan dalam tatanan kehidupan sosial sampai pada masyarakat bawah. Pelibatan masyarakat, yang berarti keterlibatan masyarakat lokal cenderung menyadari manfaat dari keterlibatan mereka dalam mitigasi dan kesiapsiagaan bencana (Pandey, 2019).

Oleh karena itu, pendekatan dan pemecahan masalah menekankan pada ketahanan masyarakat yang memiliki pengetahuan dan kepedulian yang memadai dalam menghadapi krisis. Komunitas masyarakat merupakan pilar utama dalam kehidupan sosial, sebab pada skala ini komunitas masyarakat terdorong untuk melakukan identifikasi kebutuhan dan upaya kolaborasi bersama yang diperlukan untuk memenuhinya (Mathbor, 2007). Selain itu, komunitas masyarakat menjadi ruang diskusi utuk melakukan rencana aksi yang relevan dengan program 
ketahanan terhadap krisis dalam rangka penguatan kapasitas kelembagaan (Koem, 2019; Lahay et al., 2020).

Tingkat potensi kerugian yang dialami oleh masyarakat atau komunitas akibat dari bencana, sangat ditentukan kondisi sosial, ekonomi, politik, budaya, teknis dan lingkungan yang berlaku di komunitas tersebut (DIPECHO, 2010). Kondisi dari aspek sosial masyarakat di Desa Hulawa, mayoritas berprofesi sebagai penambang sebesar $56.7 \%$ dan petani sebesar $23.3 \%$. Tingginya profesi masyarakat sebagai penambang didukung oleh potensi desa tersebut yang memiliki kawasan tambang di area pegunungan. Jarak kawasan aktivitas pertembangan dengan rumah penduduk terbilang sangat dekat yaitu berkisar antara 3 sampai $5 \mathrm{~km}$. Kondisi ini perlu menjadi perhatian bersama, jika sewaktu-waktu terjadi perubahan pada lingkungan yang dapat menyebabkan bencana.

Menurut Sunarti et al., (2017) aktivitas penambangan liar disepanjang sungai yang bergerak dari hulu ke hilir berpotensi menyebabkan peningkatan kejadian bencana seperti banjir dan banjir bandang. Selain itu, aktivitas pertambangan yang dilakukan dalam waktu yang lama dapat menyebabkan perubahan bentang alam, kemiringan lereng, ketinggian tebing galian, dan ketiadaan vegetasi. Kondisi tersebut dapat memicu kerusakan fisik akibat erosi yang ekstrim dan memicu terjadinya longsor (Ramadhan et al., 2020). Oleh karena itu, program yang dilakukan dalam meminimalisir dampak yang ditimbulkan oleh bencana dari aktivitas pertambangan perlu melibatkan masyarakat sebagai aktor utama. Program yang dilakukan dapat berupa rekrutmen dan pembentukan forum komunitas yang menjadi sasaran program. Selanjutnya komunitas tersebut dibekali dengan pengetahuan tentang identifikasi dan pemanfaatan potensi desa sehingga komunitas dapat melakukkan peran-peran praktis dalam menjanga keseimbangan ekosistem dalam konteks pengendalian bencana.

\section{METODE}

\section{Lokasi Pelaksanaan Program}

Program ini dilaksanakan di Desa Hulawa Kecamatan Sumalata Timur Kabupaten Gorontalo. Desa Hulawa merupakan pemekaran dari Desa Buladu (Gambar 1). Desa ini sebelumnya adalah sebuah dusun yang dikenal dengan nama dusun Pasolo sejak jaman penjajahan Belanda. Berdasarkan cerita dari tokoh masyarakat/orang tua, bahwa pada jaman itu tempat ini merupakan lokasi pertambangan emas secara tradisional. Tempat ini semacam paritan disungai yang lebih dikenal dengan PASOLO. Desa Hulawa terdiri dari 3 dusun yaitu Pasolo, Tengah, Pantai, dengan luas wilayah mencapai $10,12 \mathrm{~km}^{2}$. Jumlah penduduk di Desa Hulawa mencapai 602 jiwa (310 laki-laki dan 292 perempuan), jumlah kepala keluarga 147 KK. Desa ini mempunyai potensi sumber daya alam berupa perkebunan, pertambangan, hutan, air. Sebagian besar masyarakat desa Hulawa sangat bergantung pada perkebunan jagung dan pertambangan rakyat sebagai sumber ekonomi.

Program ini terdiri dari beberapa kegiatan, dengan hasil akhir yang dicapai adalah: terbentuknya Forum Masyarakat Tangguh (FORMATA) di desa Hulawa. Forum atau kelompok masyarakat penting untuk dibentuk dalam rangka membangun kerja sama dan tanggung jawab. Pembentukan komunitas atau forum ini adalah hal yang baru di desa Hulawa, dan belum pernah dilakukan sebelumnya. Dengan adanya forum, kegiatan yang akan dilaksanakan kedepannya dapat berjalan dengan baik. Adapun tahapan pelaksanaan pembentukan Forum Masyarakat Tangguh (FORMATA) desa Hulawa adalah sebagai berikut:

\section{Rekrutmen Anggota Forum Komunitas}

Setelah tahap sosialisasi maka dilakukan identifikasi calon yang akan menjadi anggota forum. Tahapan ini dilakukan melalui diskusi dengan aparat desa, karang taruna, dan kepala dusun, serta dilakukan saat wawancara dengan masyarakat. Daftar anggota forum dipilih melalui 
hasil wawancara dan jawaban responden dari hasil survey. Daftar nama ini selanjutnya akan digunakan pada kegiatan musyawarah pembentukan forum.

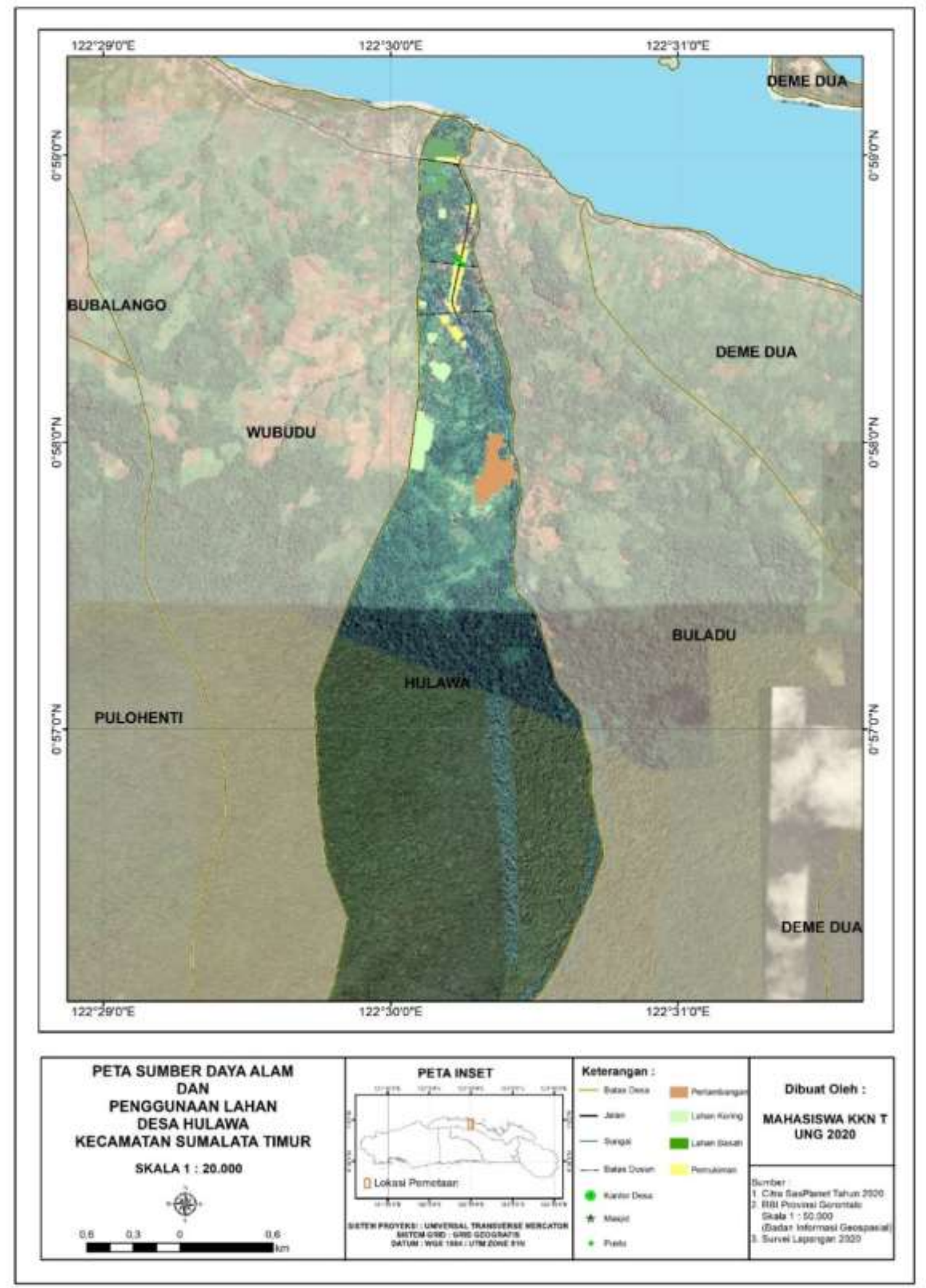

Gambar 1. Peta administrasi dan potensi sumber daya alam Desa Hulawa 


\section{Pembentukan Forum Komunitas}

Pembentukan forum dilaksanakan melalui musyawarah di aula kantor Desa Hulawa, dengan menghadirkan calon anggota forum yang telah didata sebelumnya. Kegiatan musyawarah pembentukan dimulai dengan memberikan penjelasan kepada peserta tentang tujuan, tugas dan fungsi pembentukan forum. Forum komunitas ini memiliki peran strategis dalam upaya meminimalisir bencana (Koem et al., 2019).

\section{Best Practice}

Pengumpulan data di lapangan melibatkan forum masyarakat. Keterlibatan forum masyarakat dalam best practice merupakan sarana yang efisien karena memberikan ruang bagi forum untuk saling bertukar pengetahuan dan ide dalam menawarkan solusi pemecahan maslah. Metode-metode yang diterapkan pada aspek ini diantaranya teknik pengumpulan data kuantitatif yaitu metode observasi dengan mengamati, merekam, mengukur, dan mencatatnya, secara langsung di lapangan berbasis Sistem Informasi Geografis (SIG).

\section{HASIL DAN PEMBAHASAN}

Survey Pengetahuan dan Cara Masyarakat Mengelola Sumber Daya Alam

Metode survey digunakan untuk menunjang kegiatan ini. Survey yang dilakukan berupa kunjungan langsung kepada responden. Jumlah responden yang disurvei berjumlah 30 orang yang terdiri dari aparat desa, kepala dusun, Karang Taruna dan masyarakat desa Hulawa. Berdasarkan usia responden, 60 \% berada pada rentang 21-35 tahun (Gambar 2). Adapun untuk etnis yang ada di desa Hulawa adalah Gorontalo dengan presntase $100 \%$. Pendidikan terakhir didominasi tamatan SMA keatas sekitar 53,3\% (Gambar 3). Rata- rata pekerjaan dari responden yaitu bekerja sebagai penambang di desa sendiri.

Pengetahuan responden tentang potensi sumber daya alam, diperoleh $73 \%$ masyarakat sangat mengetahui dan mengetahui kondisi dan pemanfaatan sumberdaya alam untuk menunjang kebutuhan masyarakat desa hulawa (Gambar 4). Selain itu, sumber daya alam tersebut berkontribusi besar dalam menunjang pembangunan di Desa Hulawa. Potensi tambang yang terdapat di Desa Hulawa memiliki peran starategis dalam meningkatkan ekonomi masyarakat. Namun, memiliki dampak terhadap sumber daya air sungai di Desa Hulawa. Dampak langsung yang diamati dilapangan yaitu perubahan warna pada air sungai akibat aktivitas pertambangan.

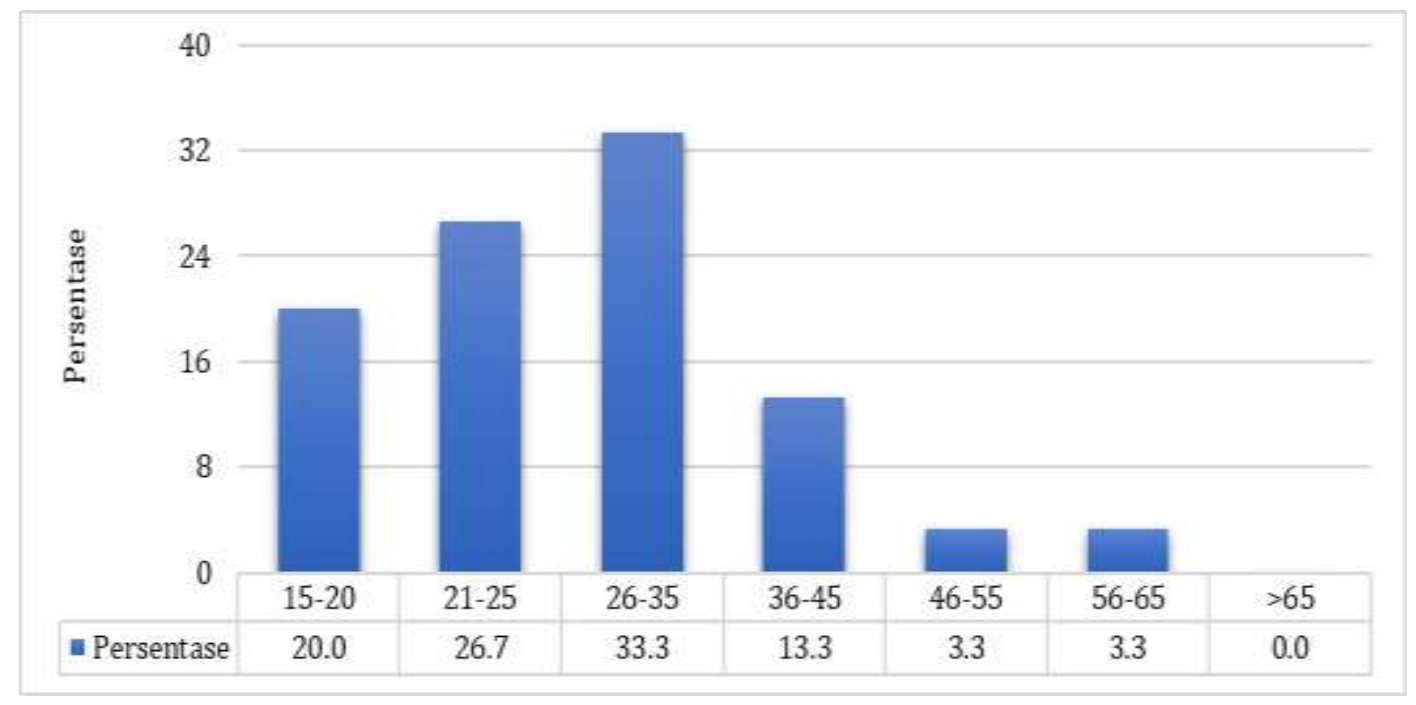

Gambar 2. Grafik umur responden 


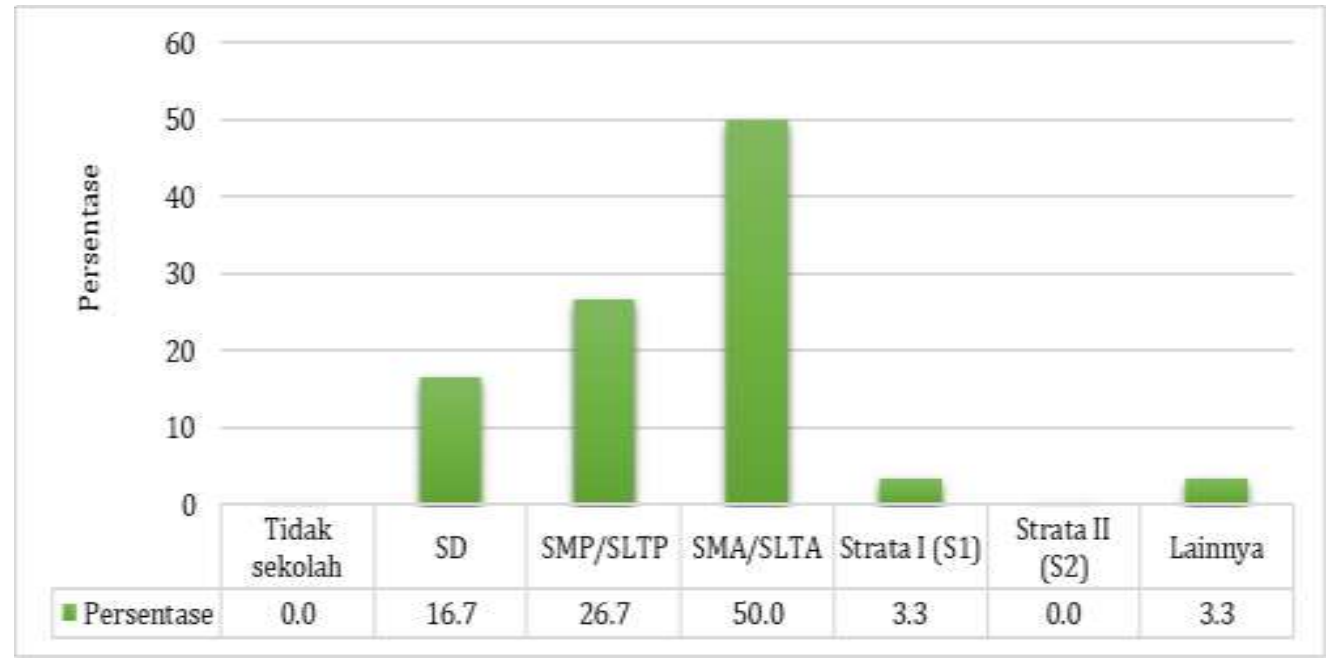

Gambar 3. Grafik tingkat pendidikan responden

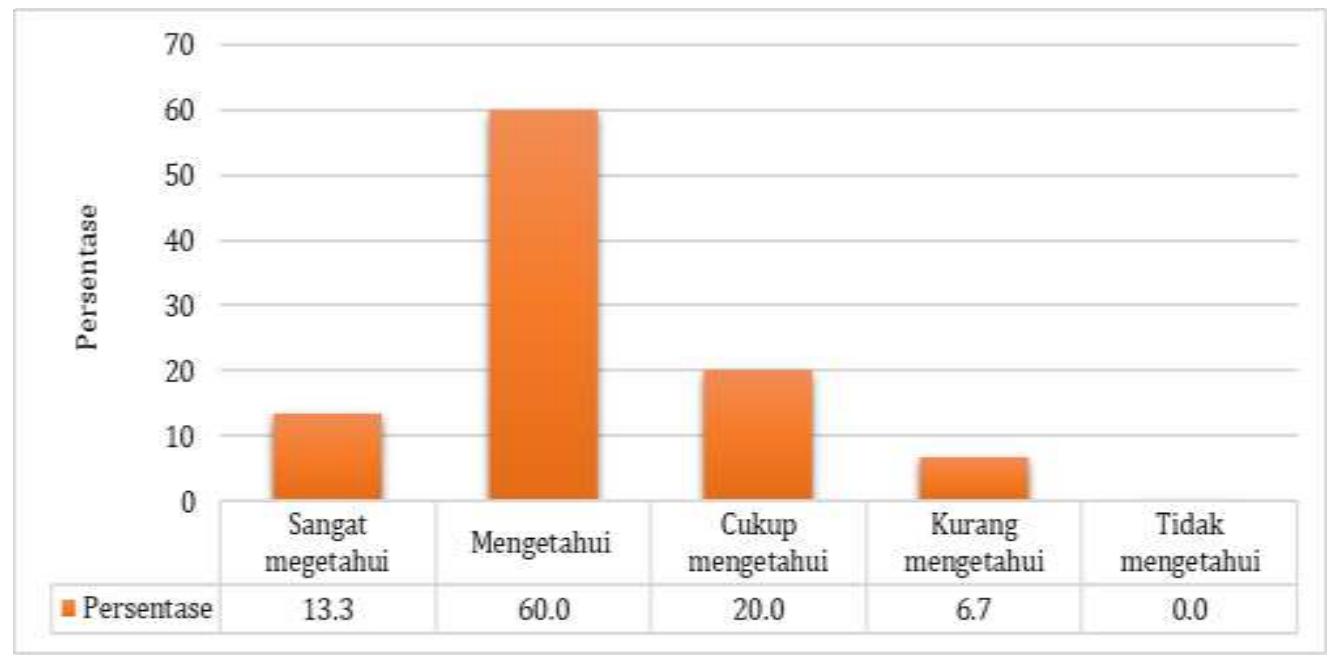

Gambar 4. Grafik pengetahuan masyarakat tentang potensi sumber daya alam

Cara masyarakat dalam mengelola sumber daya alam di Desa Hulawa memiliki banyak metode, dari potensi pertanian masyarakat mengolah hasil pertanian menjadi bahan makan untuk di jual seperti gula aren, jagung, dan kelapa. Selain itu, terdapat masyarakat yang mengolah bumbu rempah menjadi bahan makanan utuk kebutuhan sehari-hari. Untuk potensi pertambangan masyarakat mengolah secara mandiri dalam menghasilkan emas.

\section{Forum Masyarakat Tangguh (FORMATA)}

Formata merupakan sebuah forum masyarakat tangguh dalam menghadapi dan mengurangi resiko bencana berbasis sumber daya alam, lingkungan, dan kesehatan dimasa yang akan datang. Pembentukan forum ini sangat penting dikarenakan forum ini bertujuan sebagai penasehat, fasilitas dan konsultasi yang memungkinkan terjadinya penurunan risiko bencana. Melalui berbagai aspek yang dibagun melalui proses yang inklusif yang melibatkan berbagai pihak. Pembentukan forum masyarakat tangguh ini belum pernah dilakukan sebelumnya mengingat hal ini didasari akan tingkat bencana di desa ini masih tergolong rendah.

Pembentukan Forum Masyarakat Tangguh (FORMATA) diawali dengan pemilihan peserta melalui metode wawancara. Calon anggota forum masyarakat tangguh yang di wawancarai terdiri 
dari aparat desa, karang taruna, serta masyarakat setempat. Berdasarkan hasil wawancara tersebut kemudian dipilih anggota untuk bergabung dalam Forum. Selain itu, pembentukan forum menekankan pada kemampuan adaptasi anggota forum, seperti kemampuan komunikasi, pengetahuan dan sikap dalam mengurangi dan mengatasi dampak bencana. Jumlah anggota Forum sebanyak 22 orang yang telah dibentuk, selanjutnya yang tergabung dalam forum ditetapkan berdasarkan Surat Keputusan (SK) kepala desa (Gambar 5). Langkah selanjutnya ditindaklanjuti dengan rapat anggota FORMATA, sebagai upaya dalam memahamkan pentinggnya forum yang dibentuk dan mengoptimalkan potensi anggota dalam mendukung pembangunan di desa.
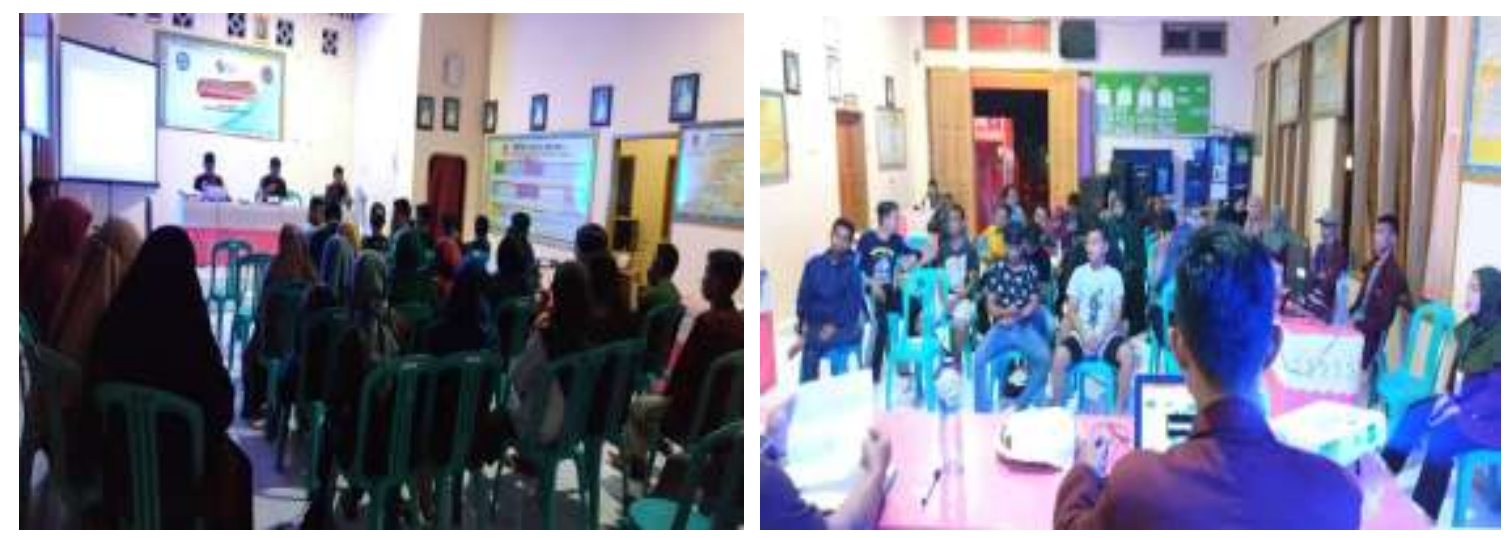

Gambar 5. Pembentukan Forum Masyarakat Tangguh (FORMATA) Desa Hulawa

\section{Identifikasi Potensi Sumber Daya Desa}

Pemetaan potensi sumber daya alam dilaksanakan dengan beberapa rangkaian sub kegiatan, dengan rincian sebagai berikut:

1. Identifikasi batas wilayah

Kegiatan ini bertujuan untuk mengidentifikasi batas dusun dan desa Hulawa. Pengumpulan informasi dilakukan dalam bentuk studi dokumentasi dan wawancara kepada tokoh masyarakat dan pemerintah desa Hulawa, sehingga ditemukan batas wilayah sebenarnya.

2. Pembuatan peta tentatif administrasi desa

Kegiatan yang dilakukan pada tahap ini adalah membuat peta tentatif yang digunakan sebagai acuan dalam melakukan peninjauan lokasi batas desa dan dusun. Selain itu, peta tersebut digunakan untuk mengidentifikasi potensi sumber daya desa. Masyarakat berpartisipasi aktif dalam memberikan informasi potensi sumber daya yang terdapat di Desa Hulawa.

3. Survey Lapangan

Kegiatan ini berupa peninjauan lokasi batas dusun dan desa, serta pengumpulan data potensi sumber daya desa. Keterlibatan karang taruna dalam memberikan informasi mengenai penggunaan dan pemanfaatan lahan oleh masyarakat digunakan sebagai rekomendasi pemanfaatan lahan kedepan. Data dan informasi lain yang dikumpulkan berupa koordinat batas desa dan dusun menggunakan GPS yang dilakukan langsung oleh masyarakat, sehingga masyarakat memperoleh pengalaman dalam menerapkan teknologi navigasi dan informasi posisi. Selain itu, mencatat tipe penggunaan/penutupan lahan dilokasi yang dikunjungi (Gambar 6). 

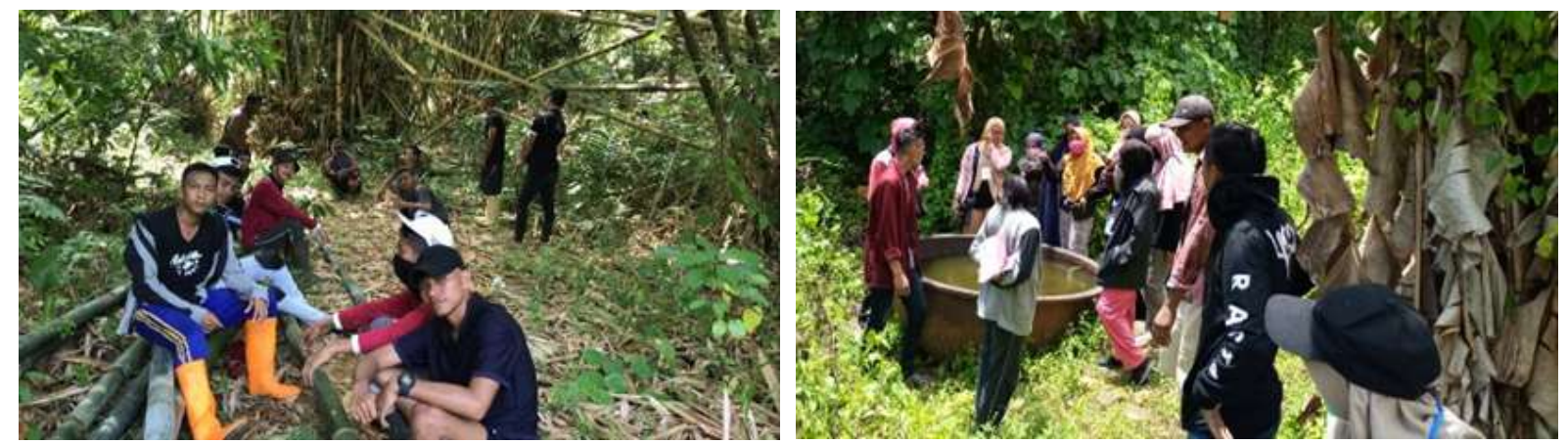

Gambar 6. Identifikasi potensi desa dan batas wilayah

\section{Sosialisasi dan FGD (Focus Group Discussion)}

Kegiatan ini diselenggarakan di aula kantor Desa Hulawa, dengan menerapkan metode ceramah, diskusi dan studi kasus (Gambar 7). Peserta yang yang terlibat dalam kegiatan ini yaitu FORMATA dan tokoh masyarakat lainnya yang terbagi menjadi beberapa kelompok diskusi (Gambar 8). Hasil indentifikasi potensi sumber daya desa yang telah dibuat dalam peta didiskusikan bersama forum dan masyarakat Desa Hulawa. Masyarakat memberikan respon positif selama sosialisasi dilaksanakan. Respon masyarakat diantaranya memberikan gambaran secara spasial posisi lahan yang pernah dan saat ini meraka manfaatkan. Hal tersebut mengidikasikan bahwa masyarakat mampu mengadopsi pemahaman mengenai sistem informasi spasial berbasis peta. Harapannya kegiatan tersebut dapat meningkatkan kapasitas masyarakat Desa Hulawa dalam mengenal dan memanfaatkan potensi desa dengan memperhatikan aspek pelestarian dan perlindungan sumber daya alam dan lingkungan.
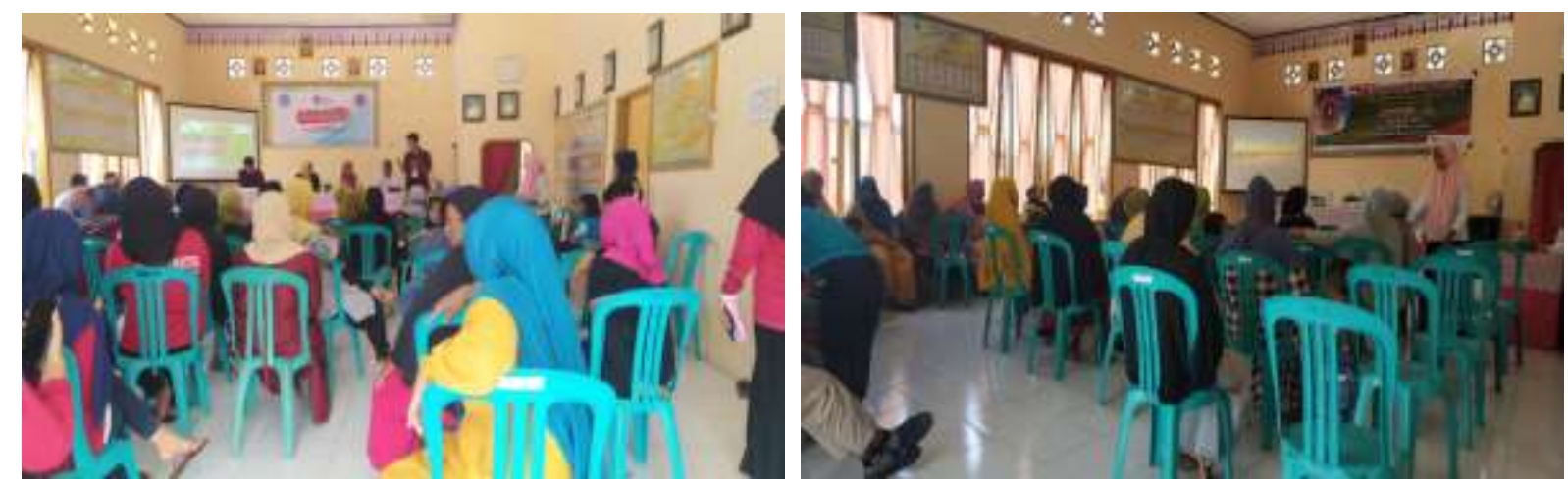

Gambar 7. Sosialisasi peran forum masyarakat dalam mengurangi risiko bencana
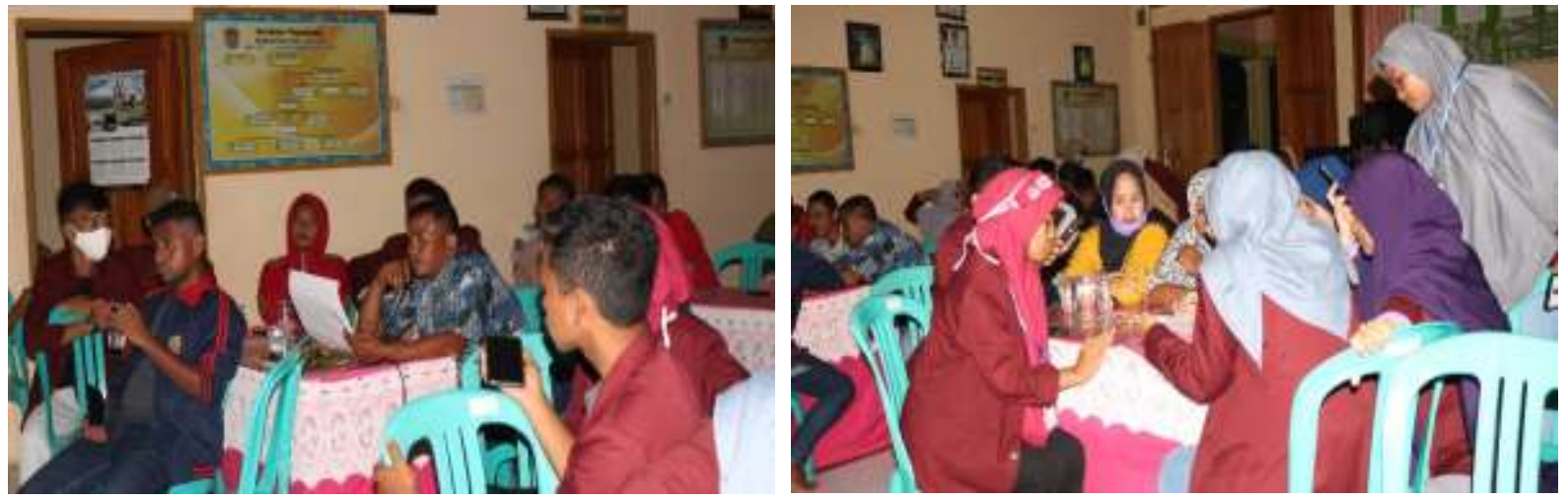

Gambar 8. FGD (Focus Group Discussion) pemetaan potensi desa berbasis SIG 
Kegiatan FGD mendorong partisipasi forum agar memberikan pandangan terkait akurasi pemanfaatan lahan dan posisi batas wilayah pada peta yang telah dibuat sebelumnya (Gambar 8). Identifikasi objek yang ada pada peta dilakukan secara bersama-sama oleh peserta dan didelineasi menggunakan alat tulis (spidol). Objek-objek pada peta yang diidentifikasi berupa jenis penggunaan/penutupan lahan, jalan, sungai, fasilitas umum, fasilitas kesehatan dan objek lainnya. Dari hasil pemetaan ini diperoleh beberapa jenis penutupan/penggunaan lahan; lahan kering, lahan basah, area tambang, dan permukiman. Identifikasi potensi berbasis peta ini mampu meningkatkan kesadaran dan pengetahun masyarakat, sehingga peta dapat dikoreksi berdasarkan masukan dari forum. Hal ini diharapakan sejalan dengan upaya masyarakat dalam melakukan upaya konservasi lingkungan dan sumber daya alam di Desa. Upaya konservasi lingkungan berbasis masyarakat dapat membantu pengembangan lingkungan yang bernilai budaya dan ekonomi tinggi (Eraku \& Koem, 2018).

Setelah menerima masukan dari forum, selanjutnya peta direvisi dan diolah kembali menggunakan perangkat lunak SIG untuk menghasilkan peta eksisting potensi sumber daya desa. Melalui metode FGD menjadi sarana bagi masyarakat dalam menyampaikan pandangan meraka, sehingga meningkatkan ketahanan masyarakat terhadap bencana. Selain itu, masyarakat mengetahui teknik pemetaan dan pemanfaatan sumber daya alam melalui FGD. Menurut Priyo \& Faizah (2020) aspek pengetahuan terhadap bencana penting bagi masyarakat, agar dapat melakukan rencana tanggap darurat dan mobilisasi sumber daya yang baik.

\section{KESIMPULAN}

Potensi desa yang dimiliki oleh Desa Hulawa dapat dimaksimalkan menjadi keunggulan desa. Pemanfaatan potensi tersebut secara langsung berdampak pada peningkatan ekonomi masyarakat (Hapsari \& Santoso, 2020). Namun, pemanfaatan potensi dilakukan secara bijaksana agar tidak berdampak negatif pada masyarakat dan linkungan. Best practice dalam konteks bencana perlu ditindaklanjuti dengan melakukan penilaian terhadap tingkat kerentanan, kapasitas, dan risiko bencana. Hal ini perlu dilakukan karena melihat peluang tingginya keterlibatan masyarakat desa Hulawa dalam program-program pemberdayaan masyarakat desa.

\section{UCAPAN TERIMA KASIH}

Penulis mengucapkan terima kasih kepada LP2M Universitas Negeri Gorontalo atas dukungan dana kegiatan pengabdian. Penulis juga mengucapkan terima kasih kepada pemerintah desa dan masyarakat Desa Hulawa Kecamatan Sumalata Timur Kabupaten Gorontalo Utara yang telah memberi dukungan terhadap pengabdian ini.

\section{DAFTAR PUSTAKA}

DIPECHO. (2010). Community-Based Best Practices For Disaster Risk Reduction. Maputo Mozambique: United Nations Development Programme (UNDP).

Eraku, S. S., \& Koem, S. (2018). Konservasi Lingkungan Berbasis Masyarakat Di Desa Motilango, Kabupaten Gorontalo Utara. Ethos: Jurnal Penelitian Dan Pengabdian, 6(1), 107-113. https://doi.org/https://doi.org/10.29313/ethos.v6i1.3554

Hapsari, M. T., \& Santoso, B. R. (2020). Pengolahan Makanan Berbasis Potensi Desa sebagai Sumber Ekonomi Kreatif Masyarakat. Dinamisia : Jurnal Pengabdian Kepada Masyarakat, 5(1), 17-24. https://doi.org/10.31849/dinamisia.v5i1.4364

Koem, S. (2019). Membangun Ketahanan Berbasis Komunitas dalam Mengurangi Risiko Bencana di Desa Pilomonu Kabupaten Gorontalo. Jurnal Pengabdian Pada Masyarakat, 4(2), 211-222. https://doi.org/10.30653/002.201942.143

Koem, S., Akase, N., \& Muis, I. (2019). Peningkatan Kapasitas Masyarakat Dalam Mengurangi Risiko Bencana Di Desa Bandung Rejo Kabupaten Gorontalo. Aksiologiya: Jurnal Pengabdian 
Kepada Masyarakat, 3(2), 176. https://doi.org/10.30651/aks.v3i2.1815

Lahay, R. J., Koem, S., \& Nasib, S. K. (2020). Adaptasi Perubahan Iklim Berbasis Masyarakat Melalui Pendekatan Ekosistem Di Desa Ilodulunga Kabupaten Gorontalo Utara. Jurnal Penelitian Dan Pengabdian Kepada Masyarakat UNSIQ. https://doi.org/10.32699/ppkm.v7i2.980

Mathbor, G. M. (2007). Enhancement of community preparedness for natural disasters. International Social Work, 50(3), 357-369. https://doi.org/10.1177/0020872807076049

Pandey, C. L. (2019). Making communities disaster resilient. Disaster Prevention and Management: An International Journal, 28(1), 106-118. https://doi.org/10.1108/DPM-05-2018-0156

Priyo, M., \& Faizah, R. (2020). Mengukur Tingkat Kesiapsiagaan Anggota PKK RT. 05 Desa Banyuraden dalam Menghadapi Bencana Gempa. Dinamisia: Jurnal Pengabdian Kepada Masyarakat, 4(3), 531-538. https://doi.org/10.31849/dinamisia.v4i3.4115

Ramadhan, N. F., Gunawan, T., \& Nugroho Adji, T. (2020). Environmental damage assessment due to traditional mining on local scale in the Wungkal Hills, Yogyakarta-Indonesia. Journal of Degraded and Mining Lands Management, 7(2), 1995-2000. https://doi.org/10.15243/jdmlm.2020.072.1995

Sunarti, E., Sumarno, H., Nugraha, D. R., \& Islamia, I. (2017). Disaster Related to Mining : Causes , Impact, and Lesson Learned. International Journal of Disaster Management, 1(1), 1-7. 